\title{
粗い領域メッシュにスプライン補間を適用して 詳細な浸水深分布を作成する手法
}

\author{
三好 学 1 ・田村 隆雄 2 -武藤 裕則 3 - 安藝 浩資 4 - 谷口 純一 5 \\ 1正会員 ニタコンサルタント株式会社 地域計画部（テ771-0122 徳島市川内町鈴江西38-2） \\ E-mail: miyoshim@nita.co.jp \\ 2正会員 徳島大学大学院准教授 理工学研究部（干770-8506 徳島市南常三島町2-1） \\ E-mail: tamura@ce.tokushima-u.ac.jp \\ 3 正会員 徳島大学大学院教授 理工学研究部（下770-8506 徳島市南常三島町2-1） \\ E-mail: muto_yas@ce.tokushima-u.ac.jp \\ 4正会員 ニタコンサルタント株式会社 企画兼地域計画部長（一771-0122 徳島市川内町鈴江西38-2） \\ E-mail: akih@nita.co.jp \\ 5 学生会員 徳島大学大学院 先端技術科学教育部博士前期課程（干770-8506 徳島市南常三島町2-1） \\ E-mail: c501541001@ tokushima-u.ac.jp
}

\begin{abstract}
本研究では, 広い領域メッシュの解析結果を狭い領域メッシュの地盤標高モデルに反映させる手法を提案する. 具 体的には, $25 \mathrm{~m}$ メッシュでの計算結果から $25 \mathrm{~m}$ メッシュ内の水体積を求め, ポンド法の概念を用いて $5 \mathrm{~m}$ メッシュの地 盤標高モデルをもとに水位に変換する. それをスプライン補間を用いてスムージングし, 水面勾配を考慮することにより, $5 \mathrm{~m}$ メッシュでの計算結果と同程度の精度の浸水深分布を得る. 各工程における浸水深分布を $5 \mathrm{~m}$ メッシュの計算結果 と比較したところ, 工程を踏むにつれて誤差が小さくなったことから, 本研究の提案手法を妥当と判断した.
\end{abstract}

Key Words: inundation inside the levee, ground altitude model, Pound-method, spline interpolation

\section{1.はじめに}

近年, 地球温暖化の影響により降雨量が増加傾向にあり, 地方都市においても内水汇濫の被害少スクが増大している. 地方都市の1つである徳島市でも, 内水被害が多発しており, 道路などの標高の低い箇所で局所冠水が発生している.

このような局所的な内水氾濫を的確に評価するには, 詳細 な地盤標高モデルによる汇濫解析を行う必要がある. 国土地 理院では, 地盤標高モデルなど汇濫解析に用いる諸条件を 公開しており,これらの情報を用いると5mメッシュの地盤標高 モデルを用いた詳細な汇濫解析ができることが知られている しかし,このような詳細な解析は, メッシュサイズが細かくなる ことにより空間的な計算量が増大寸るだけでなく, 時間的にも タイムステップを小さくする必要があり, 指数関数的に計算量 が増大寸る. そのため, リアルタイム浸水予測など限られた計 算時間で汇濫解析を行う必要がある場合には, 解析対象領 域の面積やメッシュサイズを制約されることがある.

そこで, 武田らの研究1), 2)では広い領域メッシュにおいては 二次元不定流モデルを用いて流れを解析し，その内を狭い 領域メッシュに分割し，ポンドモデルの概念を用いて水体積 を水位に変換することにより, 計算量の増大を抑止したうえで, 地盤標高を詳細に反映できるh-VA汇濫法を考案している. しか儿, 従来の広い領域メッシュの計算に水体積を水位に変 換する演算工程が毎タイムステップにおいて追加されるため, 従来より計算時間がかかることが想定される. 一方, 吉田らの
研究3)では一様な矩形断面水路の不等流計算をGPGPUによ る並列計算で行い, 高速化を図っている. 吉田らは, 計算格 子数の増加に伴い高速化率が上昇し, 格子数が $47,832 の$ 場 合に5.5倍程度の高速化が成された一方で, 要素の割り当て 処理やデータ転送時間などの増大により, 従来より計算時間 が長くなる場合があることを指摘している.

本研究では, 広い領域メッシュ(本研究では $25 \mathrm{~m}$ メッシュを 想定した.)での従来の計算と並行して行うことのできる工程を 追加することにより, 広い領域メシシュの解析結果を狭い領域 メッシュ(本研究では $5 \mathrm{~m}$ メッシュを想定した. )の地盤標高モ デルに反映させる手法を提案する.これにより, 広い領域メッ シュでの解析と概ね同じ計算時間で, 狭い領域メッシュでの 解析結果と同程度の精度の浸水深分布を得ることを期待す るものである. 具体的には, $25 \mathrm{~m}$ メッシュでの計算結果から $25 \mathrm{~m}$ メシシュ内の水体積を求め, ポンド法の概念を用いて $5 \mathrm{~m}$ メッシュの地盤標高モデルをもとに水位に変換する. それを スムージングし, 水面勾配を考慮することにより, $5 \mathrm{~m}$ メッシュ での計算結果と同程度の精度の浸水深分布を得る. そして, 本研究の提案手法における各工程の浸水深分布と $5 \mathrm{~m}$ メッ シュの計算結果(以下 Model $5_{5 \mathrm{~m}}$ を略して $\mathrm{M}_{5 \mathrm{~m}}$ といら. )の計算結 果との水位差を評価することにより, 提案手法の妥当性を検 証する. 本研究では, 道路の局所冠水などの詳細な浸水深 分布の表示を目的としているため, 当該地区を土地利用状 況から4種類に分類し,それらごとに前述した水位差を評価 することにより, 提案手法の妥当性を確認する. 


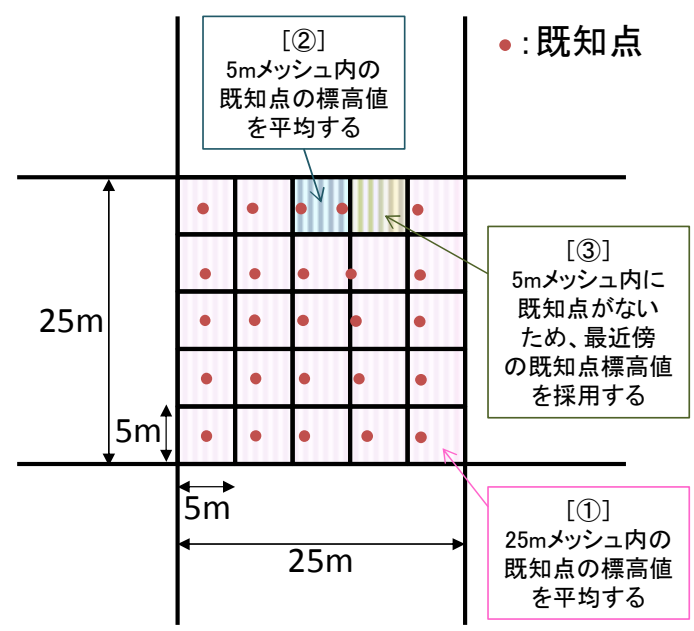

図-1２5mメッシュと5mメッシュの地盤標高モデルの作成

\section{2. 本研究で用いた手法}

\section{（1）内水汇濫解析モデル}

本研究では, 高橋ら ${ }^{4}$ や著者ら 5), のより浸水実績と計算結 果が概ね一致していることが検証されている内水流動数值 解析モデルを使用した. 本解析モデルは, 二次元不定流モ デル(地表面)，一次元開水路不定流モデル(開水路)，一 次元管水路不定流モデル(下水管路)の3個のサブモデルを 結合することにより構築されている. 下水管路モデルでは, 数 值解析の不安定化を避けるためスロットモデルを採用してい る. また, 開水路網, 雨水排水用下水管路網, 水門・樋門, 排水機場など, 実在する内水排水関連施設の効果を考慮す ることが可能である. 流れの数值計算は, 空間的には水位と 流量フラックスとをスタガード配置した正方形グリッドモデルを 差分化した. 時間的にはleap-frog法により陽的に離散化して いる.

\section{（2）詳細な地盤標高モデルへの反映}

$25 \mathrm{~m}$ メッシュと5mメッシュの地盤標高モデルの概念を図-1に 示す.まず, $25 \mathrm{~m}$ メッシュでの二次元不定流モデルによる解 析を行った. 以下, その計算結果を Model $_{25 \mathrm{~m}}$ Step1を略して $\mathrm{M}_{25 \mathrm{~m}} \mathrm{~S}_{1}$ といら. $\mathrm{M}_{25 \mathrm{~m}} \mathrm{~S}_{1}$ の解析に用いる地盤標高モデルは, 国 土地理院が公表している地盤標高モデルワにおいて $25 \mathrm{~m} メ ッ$ シュ内に既知点のある標高值を平均したものである(図-1中 (1)).

次に, 国土地理院が公表している地盤標高モデルを用い

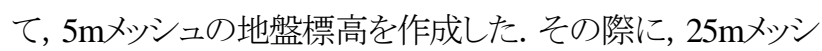
ユ内を図-1に示すように25分割することにより, $25 \mathrm{~m}$ メッシュと その内にある25個の5mメッシュにおける連続式のコントロー ルボリュームを同一のものとした. 国土地理院が公表している 地盤標高モデル $(5 \mathrm{~m}$ メシシュ)の標高值の既知点は, 緯度経 度座標での公表であるため, 平面直角座標の $5 \mathrm{~m}$ メッシュに 投影させると既知点が2つ以上存在するメッシュや既知点が

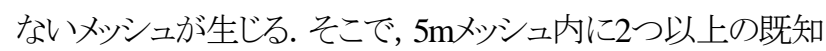
点があった場合はこれら標高值を平均したもの(図-1中(2)を， $5 \mathrm{~m}$ メシュんに既知点がなかった場合は $5 \mathrm{~m}$ メッシュの中心か

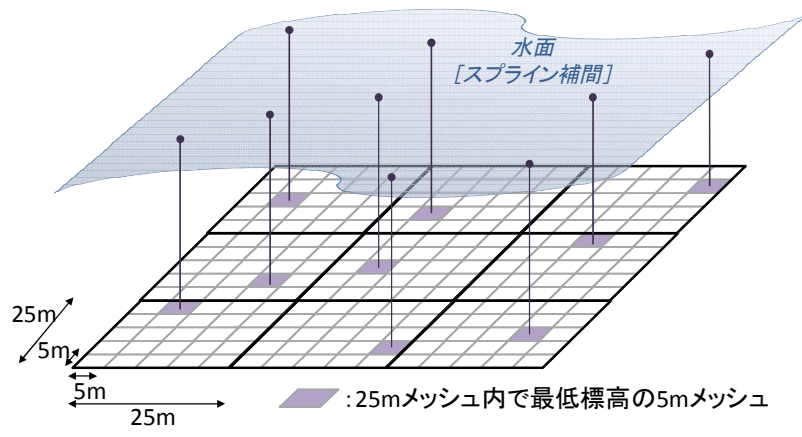

図-2 25mメッシュ内の最低標高位置の水位をもとにした スムージング

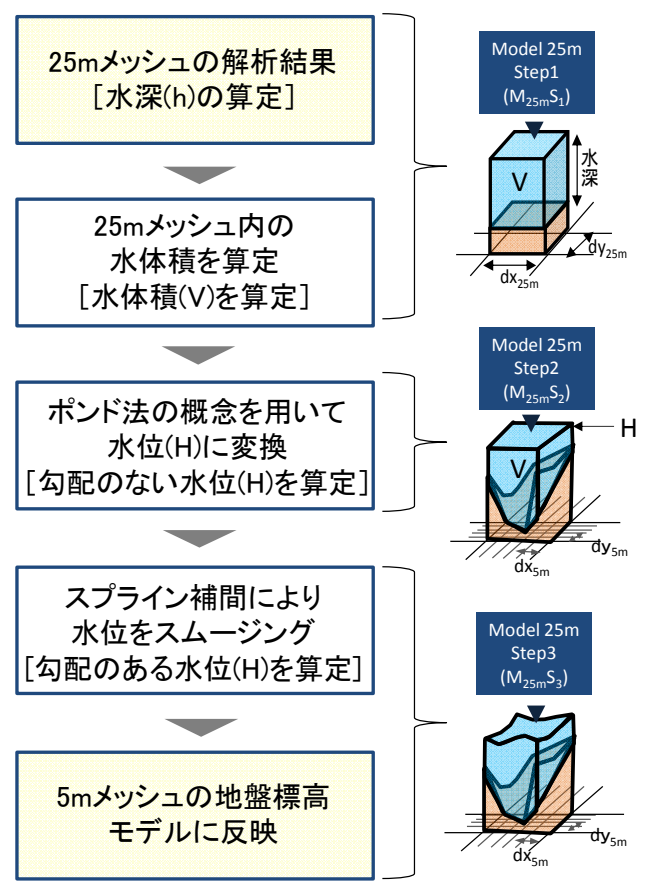

図-3 5mメッシュの地盤標高モデルへの反映の流れ

ら最近傍の既知点の標高值(図-1中(3)を 5 mメッシュの地盤 標高值とした.この5mメッシュの地盤標高モデルを用いて, 式(1)により算定された $\mathrm{M}_{25 \mathrm{~m}} \mathrm{~S}_{1}$ の $25 \mathrm{~m}$ メッシュ内の水体積 $(V)$ か ら水位 $(H)$ を求めた. その際に, 式(2)に記すようにポンド法の 概念を用い, $25 \mathrm{~m}$ メッシュ内の水位は一定とし, 標高の低い 箇所から浸水すると仮定した. 以下, この浸水深分布を Model ${ }_{25 \mathrm{~m}}$ Step2を略して $\mathrm{M}_{25 \mathrm{~m}} \mathrm{~S}_{2}$ という. $\mathrm{M}_{25 \mathrm{~m}} \mathrm{~S}_{1}$ の水位をそのまま $\mathrm{M}_{25 \mathrm{~m}} \mathrm{~S}_{2}$ の水位とすると, $25 \mathrm{~m}$ メッシュ内の起伏において平均地 盤標高より低い水位を $\mathrm{M}_{25 \mathrm{~m}} \mathrm{~S}_{1}$ は計算上考慮できないため, 平 均地盤標高以上の水位しか $\mathrm{M}_{25 \mathrm{~m}} \mathrm{~S}_{2}$ に反映されない. そこで, $\mathrm{M}_{25 \mathrm{~m}} \mathrm{~S}_{1}$ の水体積を用いて $\mathrm{M}_{25 \mathrm{~m}} \mathrm{~S}_{2}$ の水位を求めると, $\mathrm{M}_{25 \mathrm{~m}} \mathrm{~S}_{1}$ に おいて平均地盤標高より低い水位も $\mathrm{M}_{25 \mathrm{~m}} \mathrm{~S}_{2}$ に反映できると考 え, 式(2)を用いて, 水体積 $(V)$ 力况水位 $(H)$ を求めた。

$$
\begin{aligned}
V & =h_{25 m} \times d x_{25 m} \times d y_{25 m} \\
V & =\sum_{n=1}^{25}\left(H-Z b_{n, 5 m}\right) \times d x_{5 m} \times d y_{5 m}
\end{aligned}
$$

ここに, $V: 25 \mathrm{~m}$ メッシュ内の水体積 $\left(\mathrm{m}^{3}\right), h_{25 m}: \mathrm{M}_{25 \mathrm{~m}} \mathrm{~S}_{1}$ の計 
算結果の浸水深 $(\mathrm{m}), d x_{25 m}, d y_{25 m}: \mathrm{M}_{25 \mathrm{~m}} \mathrm{~S}_{1}$ の緯距, 経距方向 のメッシュ幅(m), $H: 25 \mathrm{~m}$ メッシュ内の水位 $(\mathrm{m}), Z b_{n, 5 m}: 25 \mathrm{~m}$ メッシュ内に25個ある5mメッシュの地盤標高 $(\mathrm{m}), d x_{5 m}, d y_{5 m}$ : $\mathrm{M}_{25 \mathrm{~m}} \mathrm{~S}_{2}$ の緯距, 経距方向のメッシュ幅(m)である.

この $\mathrm{M}_{25 \mathrm{~m}} \mathrm{~S}_{2}$ の浸水深分布は, $25 \mathrm{~m}$ メッシュ内に水面勾配が ないことから, $25 \mathrm{~m}$ メッシュの境界で水位の段差が生じることが 想定される. そのような場合はスムージング処理を行うことが， 現行の指針 ${ }^{8)}$ で推奨されている. 本研究では, $25 \mathrm{~m}$ メッシュ内 で最低地盤標高の5mメッシュを探索し, その位置での水位を もとにスプライン補間による水面のスムージングを行った(図2).また, $25 \mathrm{~m}$ メッシュ内に水深がない場合は, スプライン補間 の対象から除外した. 以下, この浸水深分布を Model $_{25 \mathrm{~m}} \mathrm{Step} 3$ を略して $\mathrm{M}_{25 \mathrm{~m}} \mathrm{~S}_{3}$ といら.これらの工程 $\left(\mathrm{M}_{25 \mathrm{~m}} \mathrm{~S}_{1}, \mathrm{M}_{25 \mathrm{~m}} \mathrm{~S}_{2}, \mathrm{M}_{25 \mathrm{~m}} \mathrm{~S}_{3}\right)$ は, $25 \mathrm{~m}$ メッシュの解析と並行して行うことができるため, リアル タイム浸水予測など限られた計算時間で汇濫解析を行い, 浸水深分布を表示させる必要がある場合に有効性が高いと 考える.

前述で定義した $\mathrm{M}_{25 \mathrm{~m}} \mathrm{~S}_{1}, \mathrm{M}_{25 \mathrm{~m}} \mathrm{~S}_{2}, \mathrm{M}_{25 \mathrm{~m}} \mathrm{~S}_{3}$ についてまとめたも のを図-3に示す. 先に記したように, $25 \mathrm{~m}$ メシシュの計算結果 を $\mathrm{M}_{25 \mathrm{~m}} \mathrm{~S}_{1}, \mathrm{M}_{25 \mathrm{~m}} \mathrm{~S}_{1}$ の $25 \mathrm{~m}$ メッシュ内の水体積をポンド法の概念 を用いて水位に変換した浸水深分布を $\mathrm{M}_{25 \mathrm{~m}} \mathrm{~S}_{2}, \mathrm{M}_{25 \mathrm{~m}} \mathrm{~S}_{2}$ をスフ ライン補間でスムージングした浸水深分布を $\mathrm{M}_{25 \mathrm{~m}} \mathrm{~S}_{3}$ とした.

\section{3. 徳島市で観測された内水氾濫への適用}

\section{(1) 対象降雨と対象地区}

本研究での対象降雨を図-4に示す. 対象とした降雨は平 成16年台風23号 (以下, H16T23といら. )降雨(平成16年10月 20日)である.この降雨は, $285.0 \mathrm{~mm}$ の24時間雨量と, $40 \mathrm{~mm} / \mathrm{hr}$ の最大時間雨量を徳島地方気象台において観測している. 本研究で対象とした地区は，図-5に示す徳島市渭北地区で ある. 渭北地区は, 徳島市でも比較的市街にある $2.2 \mathrm{~km}^{2}$ の地 区である. 当該地区は, 吉野川, 新町川, 助任川, 大岡川に 囲まれた中州である. また, 開水路(延長 $6.4 \mathrm{~km}$ )と下水管路 (延長15.8km)の2系統が混在し雨水を排水をしているため, 内水汇濫解析を実施すると3個のサブモデル全てを使用し, 計算負荷が大きな地区であることから, 本研究の対象とした. 開水路と下水管路の流未には排水機場や樋門が整備され

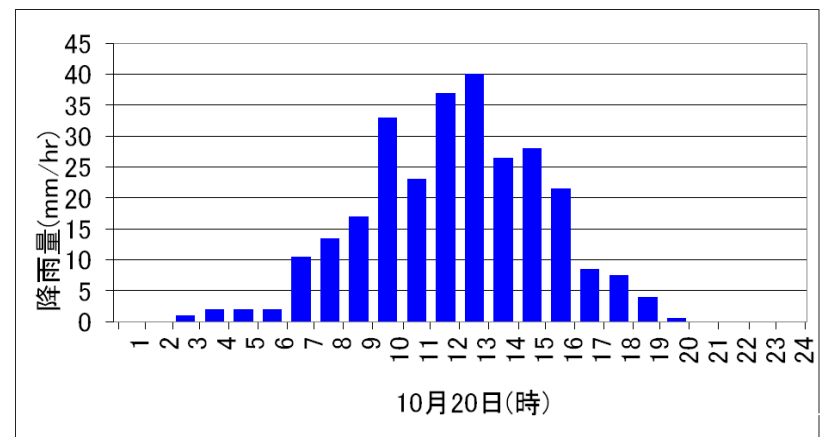

図-4 平成16年台風23号の降雨波形
おり, 豪雨時には樋門を閉め, 排水機(地区合計 $27.05 \mathrm{~m}^{3} / \mathrm{s}$ )に より堤外に強制排水している.このような排水状況を踏まえ, 本研究の内水汇濫解析では, 堤内と堤外の境界では水の流 れはないとる不透過境界しし, 排水機場位置からのみ排水 機の能力分の雨水が堤外に流出する境界条件とした.

\section{（2）本手法を用いて推定された浸水深分布}

計算メッシュ間隔と表示メッシュ間隔が異なる場合の留意点 を現行の指針9)では図一6を用いて説明している.この指針で は図一6を用いて, 広い領域メッシュの水位を, 狭い領域メッ シュの地盤標高モデル上に表示した場合に, 急勾配の地形 では階段状の浸水深が表れ，実現象にそぐわないこがある ことを指摘している. そのような場合には, 他の指針)ではスム ージング処理を行うことを推奨している.

ここで, $5 \mathrm{~m}$ メッシュでの二次元不定流モデルによる解析結 果を $\mathrm{M}_{5 \mathrm{~m}}$ といら. $\mathrm{M}_{25 \mathrm{~m}} \mathrm{~S}_{1}, \mathrm{M}_{25 \mathrm{~m}} \mathrm{~S}_{2}, \mathrm{M}_{25 \mathrm{~m}} \mathrm{~S}_{3}$ および $\mathrm{M}_{5 \mathrm{~m}}$ の平成16年 10月 20 日 14 時における浸水深分布を図-7，8，9，10に示 す.また, 四-7, 8, 9, 10には枠内を拡大した四を併せて示し た. 図-7, 9, 10の拡大図中○をみると, 四-7 $\left(\mathrm{M}_{25 \mathrm{~m}} \mathrm{~S}_{1}: 25 \mathrm{~m}\right.$ メッ シュでの解析結果)では建物が道路より一段高い箇所に立地 していることが反映できておらず, $0.50 \mathrm{~m}$ 以上 $1.00 \mathrm{~m}$ 未満の浸 水深が建物用地に存在していることがわかる. しかし, 図-9, 10をみると, $\mathrm{M}_{25 \mathrm{~m}} \mathrm{~S}_{3}$ および $\mathrm{M}_{5 \mathrm{~m}}$ は $5 \mathrm{~m}$ メッシュの地盤標高モデ ルを考慮した浸水深分布であることから, 道路から建物用地 にかけて地盤標高が高くなり, 浸水深が少なくなっていく傾 向を反映できていることがわかる. 図-9,100拡大図中○を 比較すると, $\mathrm{O}$ 部において $\mathrm{M}_{25 \mathrm{~m}} \mathrm{~S}_{3}$ では $0.50 \mathrm{~m}$ 以上 $1.00 \mathrm{~m}$ 未満 の浸水深があるものの, $\mathrm{M}_{5 \mathrm{~m}}$ ではそれがみられない.これは,

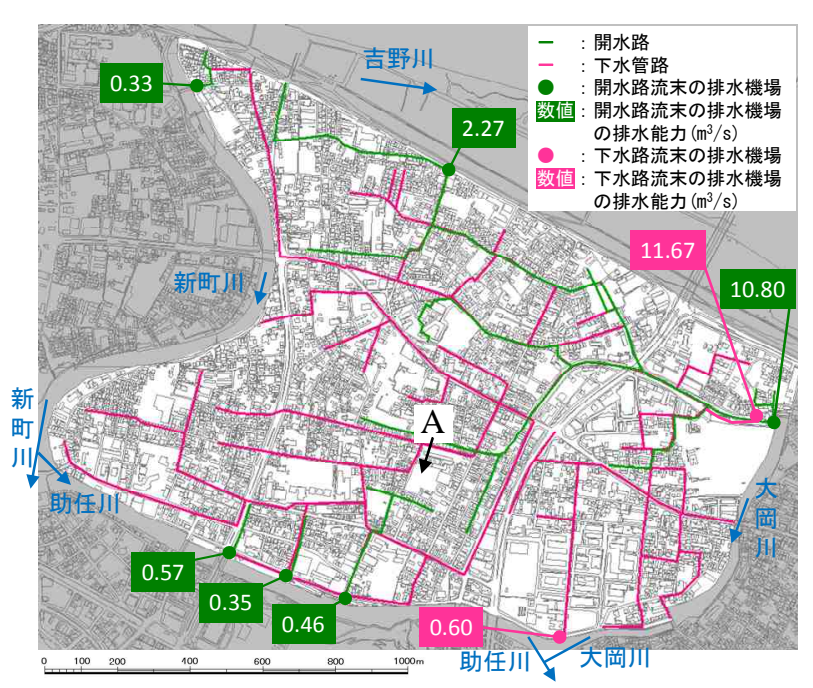

図-5 渭北地区の排水系統

急勾配の場合

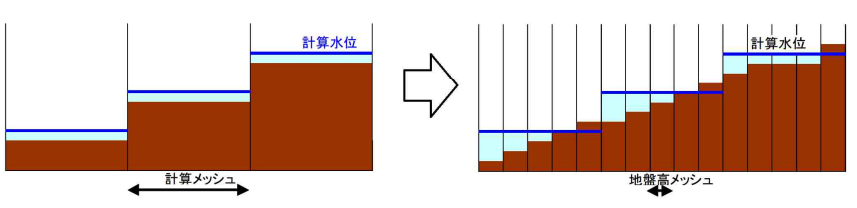

図-6 スムージング処理が推奨される事例" 
$\mathrm{M}_{25 \mathrm{~m}} \mathrm{~S}_{3}$ ではスムージングにより図-8，9，10の部の浸水と連結 したことが要因であり, 凸地により浸水位が異なる箇所では補 間精度が低〈なることが考えられる. また, 図-80拡大図中 をみると, 浸水深が $0.50 \mathrm{~m}$ 以上 $1.00 \mathrm{~m}$ 未満の箇所において, 図 -6と同様の階段状の浸水深分布が表れていることがわかる.

そのため, $\mathrm{M}_{25 \mathrm{~m}} \mathrm{~S}_{2}$ をスムージングし, $\mathrm{M}_{25 \mathrm{~m}} \mathrm{~S}_{3}$ を作成することは 妥当と考えられる.

本研究で使用したPCの性能はCPUがIntel(R) Core(TM) I74770K CPU@3.50GHzであり, RAMが8.00GBであった.この PCを用いて, 平成16年10月20日24時間分の計算にかか峙 間(タイムステップは0.10秒で計算した. )は, $\mathrm{M}_{25 \mathrm{~m}} \mathrm{~S}_{1}, \mathrm{M}_{25 \mathrm{~m}} \mathrm{~S}_{2}$, $\mathrm{M}_{25 \mathrm{~m}} \mathrm{~S}_{3}$ のそれぞれにおいて46分, 24秒, 37秒であった. その 際の $\mathrm{M}_{25 \mathrm{~m}} \mathrm{~S}_{2}, \mathrm{M}_{25 \mathrm{~m}} \mathrm{~S}_{3}$ にかかった時間は, 平成16年10月20日0 時から24時までの正時における25種類の浸水深分布図の作 成に要した時間である.このうち24種類の浸水深分布図の作 成は, $\mathrm{M}_{25 \mathrm{~m}} \mathrm{~S}_{1}$ と $\mathrm{M}_{25 \mathrm{~m}} \mathrm{~S}_{2}, \mathrm{M}_{25 \mathrm{~m}} \mathrm{~S}_{3}$ を行うPCを分離すると, $\mathrm{M}_{25 \mathrm{~m}} \mathrm{~S}_{1}$ の計算と並行して行うことができるため, $\mathrm{M}_{25 \mathrm{~m}} \mathrm{~S}_{1}, \mathrm{M}_{25 \mathrm{~m}} \mathrm{~S}_{2}$, $\mathrm{M}_{25 \mathrm{~m}} \mathrm{~S}_{3}$ に要する時間は概ね $\mathrm{M}_{25 \mathrm{~m}} \mathrm{~S}_{1}$ と同時間と考えられる. 一 方, 同 $\mathrm{PC} の \mathrm{M}_{5 \mathrm{~m}}$ における同様の計算に要した時間(タイムステ ップは0.02秒で計算した. )は8,317分であった. そのため, 本 研究の提案手法の方が $\mathrm{M}_{5 \mathrm{~m}}$ より173倍速く, $\mathrm{M}_{25 \mathrm{~m}} \mathrm{~S}_{1}$ と概ね同時 間で浸水深分布を表示できることがわかる.

計算誤差とその特徴については, 推定された浸水深分布 の検証の際に詳述するが, $\mathrm{M}_{5 \mathrm{~m}}$ の水深に対する $\mathrm{M}_{25 \mathrm{~m}} \mathrm{~S}_{1}$, $\mathrm{M}_{25 \mathrm{~m}} \mathrm{~S}_{2}, \mathrm{M}_{25 \mathrm{~m}} \mathrm{~S}_{3}$ それぞれと $\mathrm{M}_{5 \mathrm{~m}}$ との水位差の割合は最大浸水 深分布において $1.92 \%, 1.74 \%, 1.28 \%$ (図-14)之評価された.

\section{4. 推定された浸水深分布の検証}

\section{（1）本手法の検証方法}

$\mathrm{M}_{25 \mathrm{~m}} \mathrm{~S}_{1}, \mathrm{M}_{25 \mathrm{~m}} \mathrm{~S}_{2}, \mathrm{M}_{25 \mathrm{~m}} \mathrm{~S}_{3}$ と $\mathrm{M}_{5 \mathrm{~m}}$ との水位差を比較することによ り, 提案手法の検証を行う. 水位差の評価にあたっては, 式 (3)と式(4)を用いる. $25 \mathrm{~m}$ メッシュの水位は, その $25 \mathrm{~m}$ メッシュ内 にある25個の5mメッシュを支配していると考え, $\mathrm{M}_{25 \mathrm{~m}} \mathrm{~S}_{1}$ では $25 \mathrm{~m}$ メッシュ内の水位は一定とし, $25 \mathrm{~m}$ メッシュの浸水深分布 と5mメッシュの浸水深分布を比較した. また, $\mathrm{M}_{25 \mathrm{~m}} \mathrm{~S}_{1}, \mathrm{M}_{25 \mathrm{~m}} \mathrm{~S}_{2}$, $\mathrm{M}_{25 \mathrm{~m}} \mathrm{~S}_{3}$ および $\mathrm{M}_{5 \mathrm{~m}}$ ともに, 浸水深がない箇所は評価対象から 除外した.

$$
\begin{gathered}
\varepsilon=\frac{1}{n} \sum_{i=1}^{n} \frac{\left|H_{M_{25 m} S 1,2,3}-H_{M 5 m}\right|}{h_{M 5 m}} \\
\mathrm{E}=\int_{0}^{T} \varepsilon d t
\end{gathered}
$$

ここに, $\varepsilon$ :水位差の評価值(m), $H_{M 25 m S 1,2,3}: \mathrm{M}_{25 \mathrm{~m}} \mathrm{~S}_{1}, \mathrm{M}_{25 \mathrm{~m}} \mathrm{~S}_{2}$, $\mathrm{M}_{25 \mathrm{~m}} \mathrm{~S}_{3}$ のいずれかの計算結果の水位 $(\mathrm{m}), H_{M 5 m}: \mathrm{M}_{5 \mathrm{~m}}$ の計 算結果の水位 $(\mathrm{m}), h_{M 5 m}: \mathrm{M}_{5 \mathrm{~m}}$ の計算結果の水深 $(\mathrm{m}), n$ :水 位差の評価箇所数(箇所), $\mathrm{E}$ : 水位差の評価值の時間積分 $(\mathrm{m} \cdot \mathrm{hr}), T$ : 計算対象時間(本研究では24時間)(hr), $t$ : 時間 (hr)である.

\section{（2）推定された浸水深分布の妥当性の検証}

$\mathrm{M}_{25 \mathrm{~m}} \mathrm{~S}_{1}, \mathrm{M}_{25 \mathrm{~m}} \mathrm{~S}_{2}, \mathrm{M}_{25 \mathrm{~m}} \mathrm{~S}_{3}$ それぞれと $\mathrm{M}_{5 \mathrm{~m}}$ との水位差の評価值 と $\mathrm{M}_{5 \mathrm{~m}}$ の湛水量の時間変化を図-11に示す. また, 式(4)に示 した水位差の評価值の時間積分を図-12に示す. 図-11をみ ると, 計算対象時間のいずれにおいても, $\mathrm{M}_{25 \mathrm{~m}} \mathrm{~S}_{1}, \mathrm{M}_{25 \mathrm{~m}} \mathrm{~S}_{2}$, $\mathrm{M}_{25 \mathrm{~m}} \mathrm{~S}_{3}$ と工程を踏むにつれ $\mathrm{M}_{5 \mathrm{~m}}$ との水位差が小さくなることが わかる. また, 水位差の最大值は湛水量の最大值が生じた 時刻に表れていることもわかる. 図-12をみると, 水位差の評

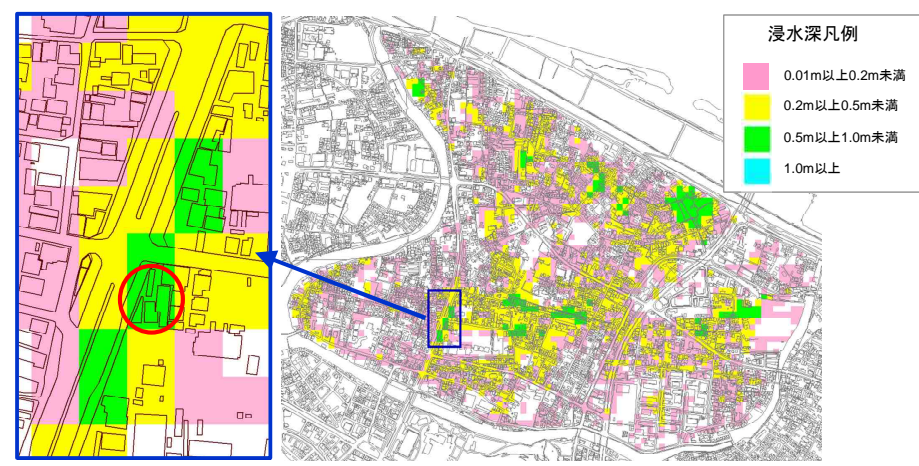

図-7 $\quad M_{25 \mathrm{I}} S_{1}$ の浸水深分布 (平成16年10月20日14時)

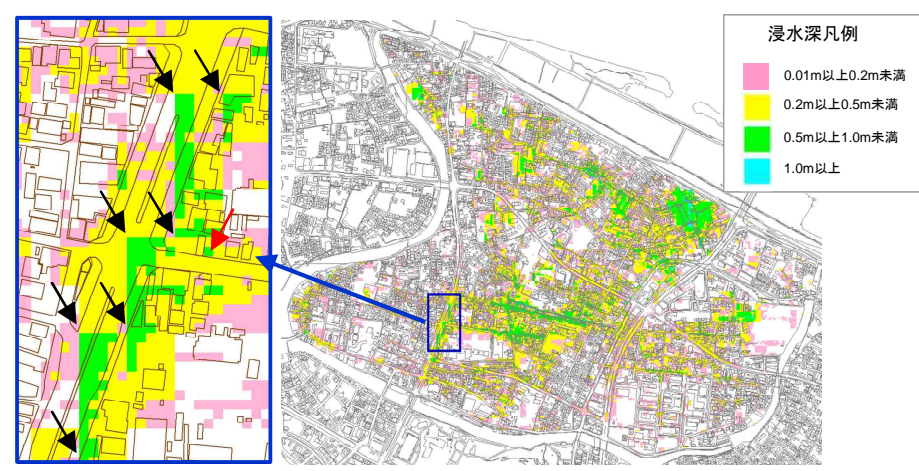

図-8 $\quad M_{2 m} S_{2}$ の浸水深分布 (平成16年10月20日14時)

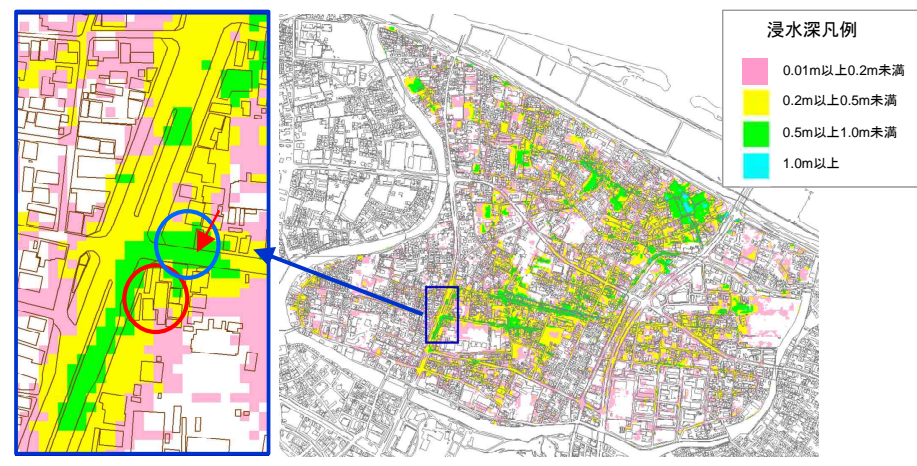

図-9 $\quad M_{25 m} S_{3}$ の浸水深分布 (平成16年10月20日14時)

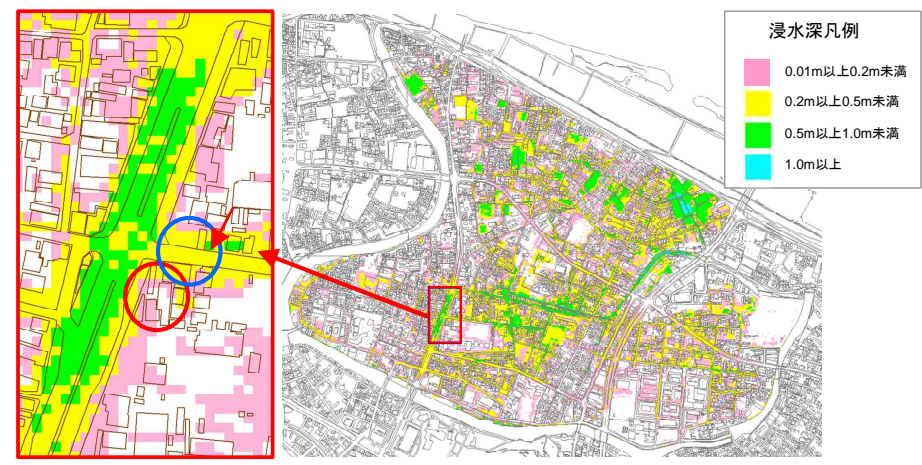

図-10 $\quad M_{5 m}$ の浸水深分布 (平成16年10月20日14時) 
価値の時間積分も, $\mathrm{M}_{25 \mathrm{~m}} \mathrm{~S}_{3}$ と $\mathrm{M}_{5 \mathrm{~m}}$ の差, $\mathrm{M}_{25 \mathrm{~m}} \mathrm{~S}_{2}$ と $\mathrm{M}_{5 \mathrm{~m}}$ の差, $\mathrm{M}_{25 \mathrm{~m}} \mathrm{~S}_{1}$ と $\mathrm{M}_{5 \mathrm{~m}}$ の差の順に小さく, $\mathrm{M}_{25 \mathrm{~m}} \mathrm{~S}_{1}, \mathrm{M}_{25 \mathrm{~m}} \mathrm{~S}_{2}, \mathrm{M}_{25 \mathrm{~m}} \mathrm{~S}_{3}$ の工 程を踏むにつれ $\mathrm{M}_{5 \mathrm{~m}}$ との水位差が小さくなることがわかる. 図 -13 は $\mathrm{M}_{5 \mathrm{~m}}$ の図-5中A地点の水位差の評価值の時間変化で ある. 図-11と同様に $\mathrm{M}_{25 \mathrm{~m}} \mathrm{~S}_{1}, \mathrm{M}_{25 \mathrm{~m}} \mathrm{~S}_{2}, \mathrm{M}_{25 \mathrm{~m}} \mathrm{~S}_{3}$ と工程を踏むに つれ $\mathrm{M}_{5 \mathrm{~m}}$ との水位差が小さくなることがわかる. また, これら水 位差とA地点の水深の時間変化の傾向は概小一致している こともわかる. 最大浸水深分布における水位差の評価值の時 間積分を図-14に示す. 図-12と同様に, $\mathrm{M}_{25 \mathrm{~m}} \mathrm{~S}_{1}, \mathrm{M}_{25 \mathrm{~m}} \mathrm{~S}_{2}$, $\mathrm{M}_{25 \mathrm{~m}} \mathrm{~S}_{3}$ の工程を踏むにつれ $\mathrm{M}_{5 \mathrm{~m}}$ との水位差が小さくなることが わかる. そのため, $\mathrm{M}_{25 \mathrm{~m}} \mathrm{~S}_{1}, \mathrm{M}_{25 \mathrm{~m}} \mathrm{~S}_{2}, \mathrm{M}_{25 \mathrm{~m}} \mathrm{~S}_{3}$ 亡工程を踏むにつ れ, $\mathrm{M}_{5 \mathrm{~m}}$ との水位差が小さくなることから, 本研究の提案手法 は妥当と考える.

\section{（3）土地利用状況ごとの浸水深分布の妥当性の検証}

国土地理院が土地利用状況 ${ }^{10)}$ 公表しているものの, $100 \mathrm{~m}$ メッシュ単位での公表であった. そのため, 住宅地図 ${ }^{11}$ 力ら目 視作業で土地利用状況を読み取り, それを本研究で用いた。 本研究で用いた当該地区の土地利用状況を図-15に示す. 土地利用状況の分類項目は, 国土地理院が公表している土 地利用状況 ${ }^{10)}$ に従い, 建物用地, 道路, その他用地(当該地 区では学校グラウンドと墓地が該当する. ), 田の4種類とした. 当該地区の現地踏査を行った際には, 道路より高い箇所に 建物が, 道路よりやや低い箇所に学校グラウンドや墓地が, 学校グラウンドや墓地より一段低い箇所に田が存在する傾向 があることを確認している.

当該地区の平成16年10月20日における4種類の土地利用 状況ごとの水位差の評価值の時間積分を図-16に示す. 図16 みると, 4 種類ともに, $\mathrm{M}_{25 \mathrm{~m}} \mathrm{~S}_{3}$ と $\mathrm{M}_{5 \mathrm{~m}}$ の差, $\mathrm{M}_{25 \mathrm{~m}} \mathrm{~S}_{2}$ と $\mathrm{M}_{5 \mathrm{~m}}$ の差, $\mathrm{M}_{25 \mathrm{~m}} \mathrm{~S}_{1}$ と $\mathrm{M}_{5 \mathrm{~m}}$ の差の順に小さく, $\mathrm{M}_{25 \mathrm{~m}} \mathrm{~S}_{1}, \mathrm{M}_{25 \mathrm{~m}} \mathrm{~S}_{2}, \mathrm{M}_{25 \mathrm{~m}} \mathrm{~S}_{3}$ と工程 を踏むにつれ $\mathrm{M}_{5 \mathrm{~m}}$ との水位差が小さくなることがわかる. また， 建物用地, 道路, その他用地に比べ, 田の水位差の評価值 の時間積分が大きいことがわかる.ここで，土地利用状況ごと に平均地盤標高を調査》したところ, 建物用地はT.P.1.71(m), 道路はT.P.1.58(m)，その他用地はT.P.1.31(m)，田は T.P.0.81(m)であり, 当該地区では田の地盤標高が顕著に低 いことがわかった. そのため, 当該地区では田は顕著に低い 特殊な地形であることが田の水位差が開きやすい要因と考 えられる.

ここで, 1 から $\mathrm{M}_{25 \mathrm{~m}} \mathrm{~S}_{1}$ と $\mathrm{M}_{5 \mathrm{~m}}$ の差に対する $\mathrm{M}_{25 \mathrm{~m}} \mathrm{~S}_{3}$ と $\mathrm{M}_{5 \mathrm{~m}}$ の差の 割合を引いたものを改善率 $i$ と定義し, 式(5)に示す.

$$
i=1-\frac{\varepsilon_{M 25 m S 3}}{\varepsilon_{M 25 m S 1}}
$$

ここに, $i$ :改善率(\%), $\varepsilon_{M 25 m S 1}: \mathrm{M}_{25 \mathrm{~m}} \mathrm{~S}_{1}$ Ł $\mathrm{M}_{5 \mathrm{~m}}$ の水位差の評価 值 $(\mathrm{m}), \varepsilon_{25 m S 3}: \mathrm{M}_{25 \mathrm{~m}} \mathrm{~S}_{3}$ Ł $\mathrm{M}_{5 \mathrm{~m}}$ の水位差の評価值(m)である.

平成16年10月20日の水位差の評価值の時間積分における 地区全体と土地利用状況ごとの改善率を図-17に示す. 図一 17をみると，4種類の土地利用状況ともに改善率は概ね一致
しており顕著な差はみられない.これらは, 地区全体の改善 率とも概ね一致しており, 土地利用状況の変化から改善率の 顕著な差はみられないことがわかる。

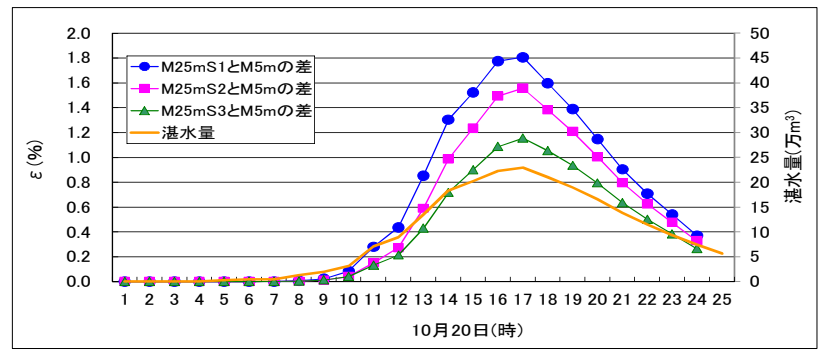

図-11 水位差の評価値の時間変化

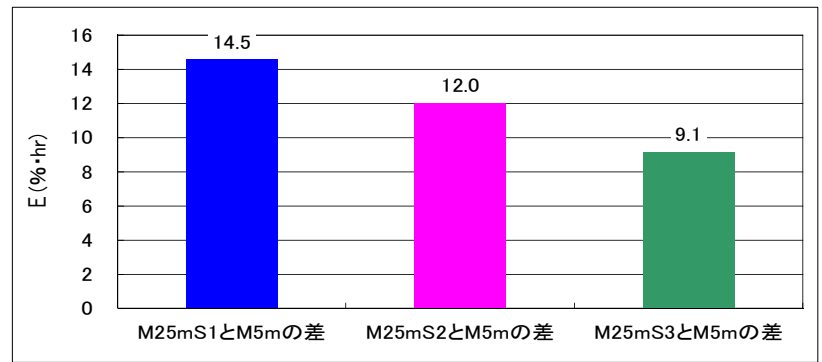

図-12 水位差の評価値の時間積分

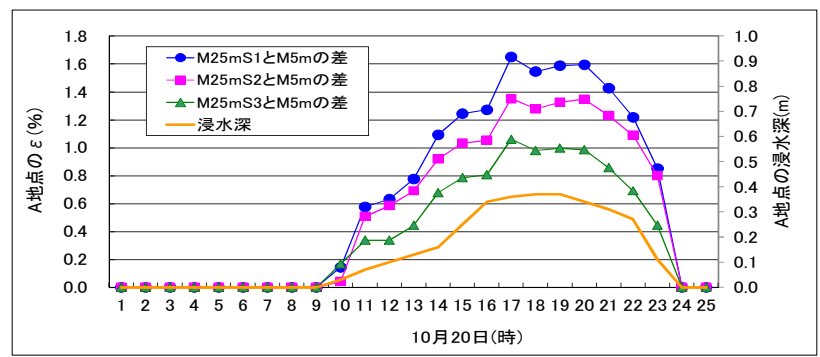

図-13 代表地点の水位差の評価値の時間変化

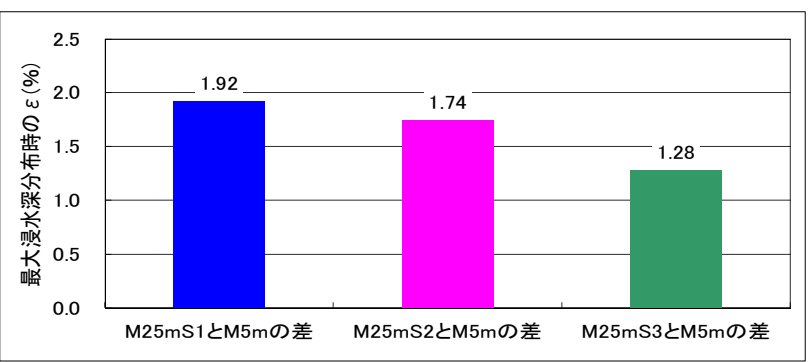

図-14 最大浸水深分布における水位差の評価値の時間積分

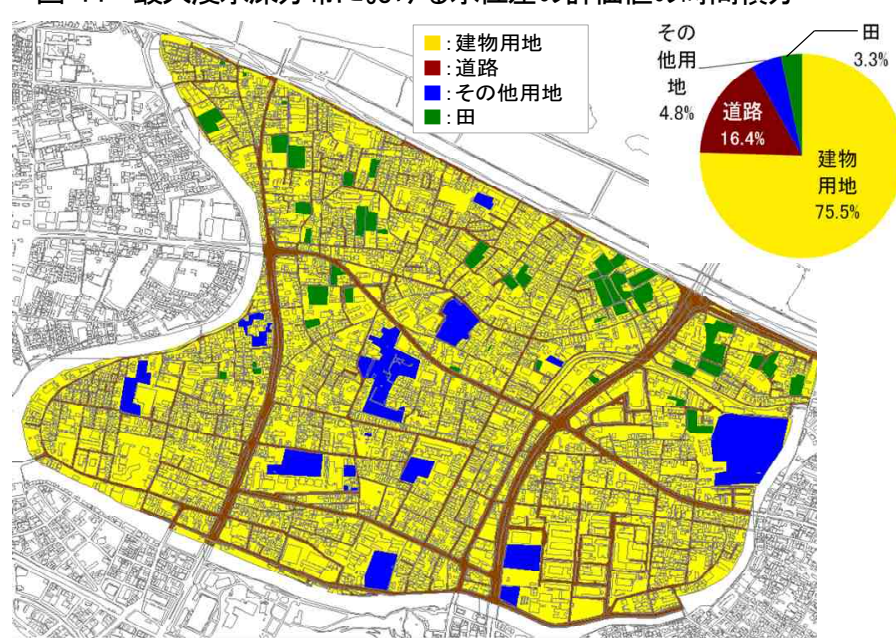

図-15 土地利用状況 (住宅地図 ${ }^{11)}$ より作成) 


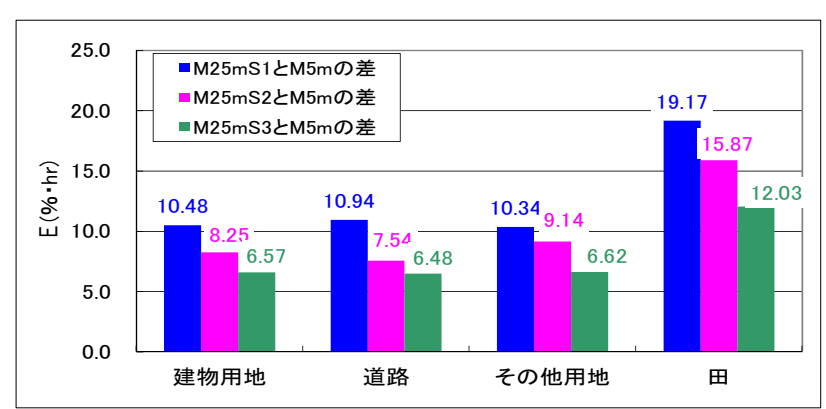

図-16 土地利用状況ごとの水位差の評価值の時間積分

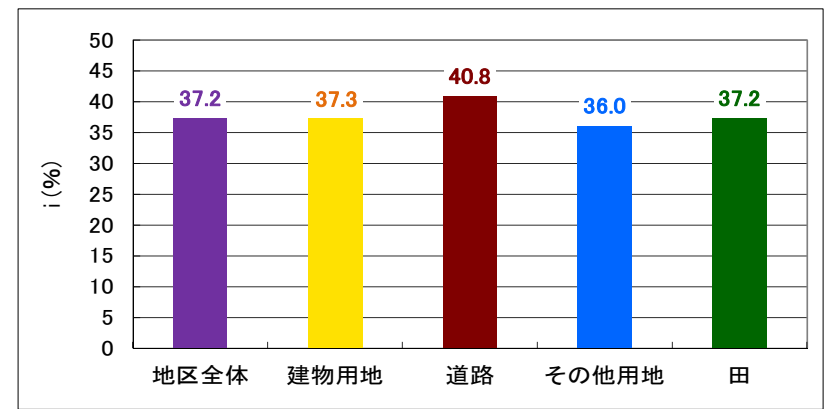

図-17 土地利用状況ごとの改善率

\section{5. まとめ}

本研究では, 徳島市渭北地区を対象とし, 広い領域メッシ ユの解析結果を狭い領域メッシュの地盤標高モデルに反映 させる手法を提案した. その結果, 広い領域メッシュの計算 時間 46 分に対し本研究の提案手法の計算時間 48 分と, 狭 い領域メッシュの計算時間(8,317 分)の 173 倍速く, 広い領域 メッシュの解析結果 $\mathrm{M}_{25 \mathrm{~m}} \mathrm{~S}_{1}$ より, $\mathrm{M}_{5 \mathrm{~m}}$ に 37.2\%近い狭い領域 メッシュでの浸水深分布 $\mathrm{M}_{25 \mathrm{~m}} \mathrm{~S}_{3}$ を得ることできたと考える. 本 研究において, 以下の(1)(2)の知見を得た.

\section{（1）推定された浸水深分布の妥当性の検証}

H16T23時において, $\mathrm{M}_{25 \mathrm{~m}} \mathrm{~S}_{1}, \mathrm{M}_{25 \mathrm{~m}} \mathrm{~S}_{2}, \mathrm{M}_{25 \mathrm{~m}} \mathrm{~S}_{3}$ それぞれと $\mathrm{M}_{5 \mathrm{~m}}$ との水位差の評価值をとったところ, 水位差の評価值の時間 変化は, $\mathrm{M}_{25 \mathrm{~m}} \mathrm{~S}_{1}, \mathrm{M}_{25 \mathrm{~m}} \mathrm{~S}_{2}, \mathrm{M}_{25 \mathrm{~m}} \mathrm{~S}_{3}$ の工程を踏むことにより, $\mathrm{M}_{5 \mathrm{~m}}$ との水位差が小さくなることがわかった. また, 水位差の評価 值の時間積分も, 時間変化々同様に, $\mathrm{M}_{25 \mathrm{~m}} \mathrm{~S}_{1}, \mathrm{M}_{25 \mathrm{~m}} \mathrm{~S}_{2}, \mathrm{M}_{25 \mathrm{~m}} \mathrm{~S}_{3}$ と工程を踏むにつれ， $\mathrm{M}_{5 \mathrm{~m}}$ との水位差が小さくなることがわか った.

\section{（2）土地利用状況ごとの浸水深分布の妥当性の検証}

当該地区を建物用地, 道路, その他用地，田に分類し，土 地利用状況ごとに水位差の評価值をとつたところ，4種類とも に $\mathrm{M}_{25 \mathrm{~m}} \mathrm{~S}_{1}, \mathrm{M}_{25 \mathrm{~m}} \mathrm{~S}_{2}, \mathrm{M}_{25 \mathrm{~m}} \mathrm{~S}_{3}$ の工程を踏むことにより $\mathrm{M}_{5 \mathrm{~m}}$ との水 位差が小さくなることがわかった. また, 周囲から一段低く, 顕 著な高低差のある箇所では, 本研究の提案手法と $\mathrm{M}_{5 \mathrm{~m}}$ との水 位差が大きくなると考えられた。

最後に本研究の提案手法は, 広い領域メッシュの解析と並 行して行うこともできるため, リアルタイム浸水予測など限られ た計算時間で汇濫解析を行い, 浸水深分布を表示させる必 要がある場合に有効性が高いと考えられる.

\section{参考文献}

1) 武田誠, 松尾直規, ポカレルパラメソル:h-VA氾濫解析法を用い たネステイングモデルに関する検討, 水工学論文集, Vol.53, pp.835-840, 2009.

2) 武田誠, 松尾直規:下水道解析を考慮したh-VA汇濫解析モデル に関する検討, 水工学論文集, Vol.54, pp.895-900, 2010.

3) 吉田圭介, 田中龍二, 前野詩朗:GPUによる分流を含む洪水流 計算の高速化, 水工学論文集, Vol.71, No.4, pp.__589-I_594, 2015.

4) 高橋賢司, 岡部健士:平成16年台風23号による徳島市佐古地区 の内水被害の数值解析, 土木学会四国支部平成18年自然災害 フォーラム論文集, pp.9-20, 2006.

5) 三好学, 田村隆雄, 安芸浩資:面積割合の加重平均の逆算によ る土地利用形態別流出係数の推定方法, 水工学論文集, Vol.71, No.4, pp.__1315-I_1320, 2015.

6) 三好学, 田村隆雄, 武藤裕則, 安芸浩資:都市郊外部における 排水路基底流量を考慮した内水氾濫解析, 水工学論文集, Vol.72, No.4, pp.__139-I_144, 2016.

7) 国土交通省国土地理院:基盤地図情報 数值標高モデル $5 \mathrm{~m} ッ$ シュ, 2015.11.

8) 国土交通省水管理・国土保全局下水道部:内水浸水想定区域 図作成の手引き, p.12, 2015.7.

9) 国土交通省北陸地方整備局:急流河川における浸水想定区域 検討の手引き, p.28, 2003.9.

10）国土交通省国土地理院:国土数值情報 土地利用細分メシシュ データ, 2012.3.

11) 株式会社ゼンリン:ゼンリン住宅地図 徳島県徳島市, pp.56-94, 2015.8.

(2016.9. 30 受付)

\title{
A PRODUCING METHOD OF DETAILED FLOOD DEPTH DISTRIBUTION ON THE GROUND ALTITUDE MODEL FROM ROUGH FLOOD ANALYSIS AND SPLINE INTERPOLATION
}

\author{
Manabu MIYOSHI, Takao TAMURA, Yasunori MUTOU, Hiroshi AKI, and Junichi TANIGUCHI
}

The method for estimating detailed flood depth distribution from a rough mesh analysis in a short time was proposed. Pound method and the spline interpolation are applied to the calculated flood depth obtained by $25 \mathrm{~m}$ mesh model. And, the estimated value near the analytical result of $5 \mathrm{~m}$ mesh is obtained on the ground altitude model. The following findings were obtained. (1)Analytical time of the proposal method was $1 / 173$ against $5 \mathrm{~m}$ mesh analysis time. (2)The difference of average flood depth between the proposal method and $5 \mathrm{~m}$ mesh analysis was $9.1 \%$ in an analytical object region. It is thought that produced method is profitable for a real-time flood forecast. 